\title{
DC Polarographic and Plane Polarographic investigation of the reduction of Thallium(I) - Aqueous systems at dropping mercury electrode
}

\author{
Subramanian, P.A ${ }^{* 1}$ and Kalyanasundaram, $\mathbf{R}^{2}$ \\ ${ }^{1}$ Department of Chemistry, CNCS, Meklle University, Mekelle, Ethiopia \\ ${ }^{2}$ Govt. Arts College (Retd.), Bharathiar University, Tamilnadu \\ (*pasubramanian@gmail.com)
}

\begin{abstract}
The reduction behavior Thallium (I) at DME has been studied by several authors with different equivalent circuits and arrived at varying results. The complexity is due to the rapid reduction process and the adsorption behavior in the mercury solution interface. So, a thorough investigation was carried out on the reduction behavior of Thallium(I) at DME using DC polarographic and impedance methods assuming Randles and Laitinen (1955) basic equivalent circuit to hold good. The investigation was carried out in three different supporting electrolytes, sodium perchlorate, potassium nitrate and potassium chloride and for four different concentrations of depolariser. The double layer capacity was obtained by extrapolation method for all the systems. The reactant adsorption was established in the supporting electrolytes, potassium nitrate and potassium chloride. In the case of sodium perchlorate a different behavior was observed. Further theoretical phase sensitive ac polarograms are drawn to confirm the results. In all the systems, Thallium (I) proceeds with high degree of reversibility and the values of $\mathrm{K}_{\mathrm{sh}}$ were found to be greater than one.
\end{abstract}

Key words: Thallium, Impedance analysis, Plane Polarography, DC polarography.

\section{INTRODUCTION}

The faradaic impedance technique is the best choice for the determination of kinetic parameters for rapid electrode processes like the reduction of Thallium(I). Randles(1947) first showed that the reduction of Thallium(I) proceeds reversibly by impedance technique. But they could not determine $\mathrm{K}_{\mathrm{sh}}$ value. Later they investigated the problem with Laitinen and reported a value for $\mathrm{K}_{\mathrm{sh}}$ as 1.8 in $1 \mathrm{M}$ perchloric acid as supporting electrolyte assuming a different equivalent circuit (Randles and Laitinen, 1955). Tamamushi and Tanaka (1961) reported that the anomaly in $\cot \varphi$ in Thallium(I) must be due to adsorption of Tl(I) ions at the mercury solution interface. The effect of adsorption on the faradaic process has been considered by several investigators (Llopis et al., 1959; Senda et al., 1961; Lorenzand salie 1961). Baticle and Perdu (1967)rigorously treated Thallium(I) system on the basis of Senda and Delahay's (1961) circuit and conducted six experiments (Baticleet al., 1967). In three experiments they could get only zero and in the remaining two, a very low value for the charge transfer resistance. Timmer et al. (1968) expressed the view that simple Randles and Laitinen (1955) circuit holds good only in the case of weak adsorption and in the case of strong adsorption they recommended a different equivalent 
circuit. D.C., A.C. and Complex Plane Polarographic behavior of copper (II) in monoethanolamine/sodium perchlorate/monoethanolammonium perchlorate solutions have been investigated by (Sridhar and subramanya, 2010).

In the present paper it is proposed to study Thallium(I)- aqueous systems in three different supporting electrolytes using the basic and simple Randles and Laitinen(1955) equivalent circuit. The same system in 50\%methanol-water mixtures has been reported recently(Subramanian and Kalyanasundaram, 2012). The determination of double layer capacity ' $\mathrm{C}_{\mathrm{d}}$ ' in the presence of reactant adsorption is very difficult to ascertain and many earlier investigators failed in this regard. So, they referred to many complicated equivalent circuits to determine the charge transfer resistance. In this work it will be done by graphical extrapolation method (Smith et al., 1966; Somayaji et al., 1969). The $\mathrm{C}_{\mathrm{d}}$ of the supporting electrolyte will be different from that of the solution in the presence of reactant adsorption. Experimental parallel capacity ' $\mathrm{C}_{\mathrm{P}}$ ' values are plotted against $1 / \omega$ and the limiting value as $\omega \rightarrow \infty$ can be found on the ' $\mathrm{C}_{\mathrm{P}}$ ' axis on extrapolation. The $\mathrm{C}_{\mathrm{d}}$ of supporting electrolyte can be directly measured. Theoretical phase sensitive ac polarograms are drawn to ascertain the reactant adsorption. The charge transfer resistance $\Theta$ and Warburg coefficient $\sigma$ can be obtained from the plots drawn with faradaic impedances $Z_{\mathrm{f}}^{\prime}$ and $\mathrm{Z}_{\mathrm{f}}$ versus $1 / \mathrm{N}_{\omega}$.

\section{MATERIALS AND METHODS}

\subsection{Apparatus and Chemicals}

Recording DC Polarograph: DC polarograms were obtained using 'Systronics' make(Model:1632, India) console using three electrode assembly and a recorder. Pure nitrogen gas was used to purge the dissolved Oxygen gas. Saturated calomel electrode was used as reference electrode.

\subsubsection{Complex plane polarography}

A manual Impedance measurement bridge of Wien bridge type was used to measure the cell impedance. The equivalent circuit of the cell is given by double layer capacitance in series with the solution resistance. Systronics make (model:1013) function generator was used to superimpose a small amplitude sine wave signal(peak to peak $10 \mathrm{mV}$ ).Polarizing circuit was provided by a 'Osaw' make potentiometer.3V DC input was given to the potentiometer. The impedance bridge setup was essentially the same as that used by Sluyters-Rehbach and Sluyters, 
(1963a \&b). The same cell assembly was used to take impedance measurements. The detector circuit was isolated from the bridge network by a balanced transformer. Output signal was amplified by an amplifier made up of 'operational amplifier integrated circuits' (No: TLO71CN). The operational range of ac signal is from $400 \mathrm{~Hz}$ to $10000 \mathrm{~Hz}$. The amplified signal was displayed in an Oscilloscope (Phillips Make model: PM3213).The adjustments of capacitance and resistance are usually made so that the balance is attained at the end of drop life. From the experimental values of $\mathrm{R}_{\mathrm{E}}$ and $\mathrm{C}_{\mathrm{E}}$ which are connected in series, the real and imaginary components (Z',Z'') of cell impedance were calculated. The accuracy of the impedance bridge was ascertained by comparing the results with the data obtained by Grahame (1949) with respect to tenth-normal solution of potassium chloride. A stock solution of $10 \mathrm{mM}$ Thallium(I) was prepared from $\mathrm{BDH}(\mathrm{AR})$ salts using double distilled water. Stock solutions (1M) of Potassium perchlorate, Potassium nitrate and Potassium chloride (supporting electrolytes) were prepared from E.Merck samples using distilled water. Triton-X-100 (0.08\%)was used as maximum suppressor while taking DC polarograms.

DC Polarograms were obtained for $2 \mathrm{mM}$ Thallium(I) in $0.5 \mathrm{M}$ sodium perchlorate, $0.5 \mathrm{M}$ potassium nitrate and $0.5 \mathrm{M}$ potassium nitrate. From the polarogram $\mathrm{E}_{1 / 2}$ values are determined. The log plots were drawn and the slope values are calculated. Complex plane polarography of $0.3 \mathrm{mM}$ Thallium(I) was obtained at $750 \mathrm{~Hz}$.in the potential range corresponding to the rising portion of the wave in DC polarograms. ' $\mathrm{q}$ ' is determined from the equation $=1 / \mathrm{Y}$ ' $\mathrm{el}$ and it is plotted against potential. The minimum in the plot corresponds to the peak potential.

The frequency variation experiments were conducted from $400 \mathrm{~Hz}$ to $10,000 \mathrm{~Hz}$ for four different concentrations, $0.3,0.4,0.5$ and $0.6 \mathrm{mM}$ of Thallium (I) in all the three supporting electrolytes at the peak potentials.

The series resistance $R_{\Omega}$ is an important parameter and it is determined by three different methods and compared.

1) Extrapolation of Z' vs Z' plots to infinite frequency,

2) Experimentally measured resistance $R_{E}$ vs $1 / \omega$ plots as $\omega \rightarrow \infty$ and 3$) R_{E}$ vs $1 / \omega^{2}$ plots as $\omega \rightarrow \infty$.

The Randles and Laitinen (1955) equivalent circuit followed in this work is given below. 


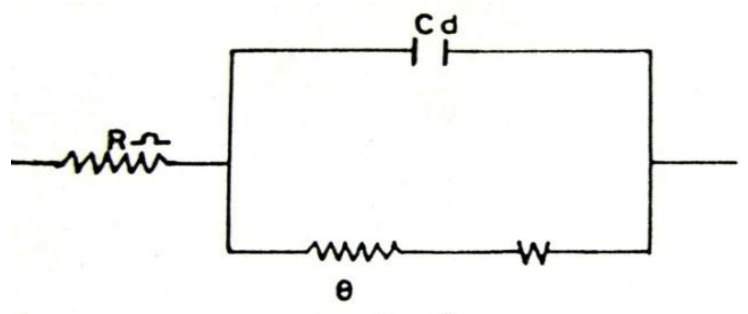

Various parameters of impedance used in this work and their relations are given below.

Experimentally determined values: Resistance $=\mathrm{R}_{\mathrm{E}} ;$ Capacitance $=\mathrm{C}_{\mathrm{E}}$; Real component of cell impedance $Z^{\prime}=\mathrm{AR}_{\mathrm{E}} ; \mathrm{A}=$ area of mercury drop, ; Imaginary component of cell impedance $\mathrm{Z}^{\prime}$ $=\mathrm{A} /\left[2 \Pi \mathrm{fC}_{\mathrm{E}}\right] ; \mathrm{f}=$ frequency; Real component of Electrode impedance $\mathrm{Z}{ }_{\text {el }}=\mathrm{Z}{ }^{\prime}-\mathrm{R}_{\Omega} ; \mathrm{R}_{\Omega}=$ Series Resistance; Imaginary component of Electrode impedance Z' el = Z' ; Real component of electrode admittance $\mathrm{Y}^{\prime}{ }_{\mathrm{el}}=\mathrm{Z}^{\prime}{ }_{\mathrm{el}} /\left(\mathrm{Z}^{\prime}{ }_{\mathrm{el}}^{2}+\mathrm{z}^{\prime}{ }_{\mathrm{el}}{ }^{2}\right)$; Imaginary component of electrode admittance $\mathrm{Y}^{\prime}{ }_{\mathrm{el}}=\mathrm{Z}{ }^{\prime}{ }_{\mathrm{el}} /\left(\mathrm{Z}_{\mathrm{el}}{ }^{2}+\mathrm{z}^{\prime}{ }_{\mathrm{el}}{ }^{2}\right)$; Real component of faradaic impedance $Z^{\prime}{ }_{\mathrm{f}}=\mathrm{Y}{ }_{\mathrm{el}} /\left(\mathrm{Y}{ }^{\prime}{ }_{\mathrm{el}}^{2}+\mathrm{Y}{ }^{\prime}{ }_{\mathrm{el}}{ }^{2}\right)$ Imaginary component of faradaic impedance $\mathrm{Z}{ }^{\prime}{ }_{\mathrm{f}}=\mathrm{Y}{ }^{\prime}{ }_{\mathrm{el}} /\left(\mathrm{Y}^{\prime}{ }_{\mathrm{el}}{ }^{2}+\mathrm{Y}^{\prime}{ }^{\prime}{ }_{\mathrm{el}}{ }^{2}\right) ; \mathrm{Y}^{\prime}{ }_{\mathrm{el}}$ and $\mathrm{Y}{ }^{\prime}{ }_{\mathrm{el}}$ are related by the equation, $Y^{\prime}{ }^{\prime}{ }_{\mathrm{el}}=\left[\mathrm{Y}^{\prime}{ }_{\mathrm{el}} /[\mathrm{p}+1]\right]+\omega \mathrm{C}_{\mathrm{d}}$ where $\mathrm{p}=\Theta /\left[\sigma \omega^{-1 / 2}\right]$

Double layer capacity: Double layer capacity, $\mathrm{C}_{\mathrm{d}}$ at the peak potential in the presence of depolarizer was determined by four different methods.

Parallel capacity, Cp Vs $\omega^{-1}$ plots: Somayaji and Subramanya (1969) showed that the double layer capacity can be determined by plotting parallel capacity against $\omega^{-1}$ plots. This is possible even in the case of reactant adsorption. $\mathrm{C}_{\mathrm{p}}$ can be determined directly by adjusting the bridge network slightly or it can be obtained by circuit analysis. The circuit analysis is given in the figure below.

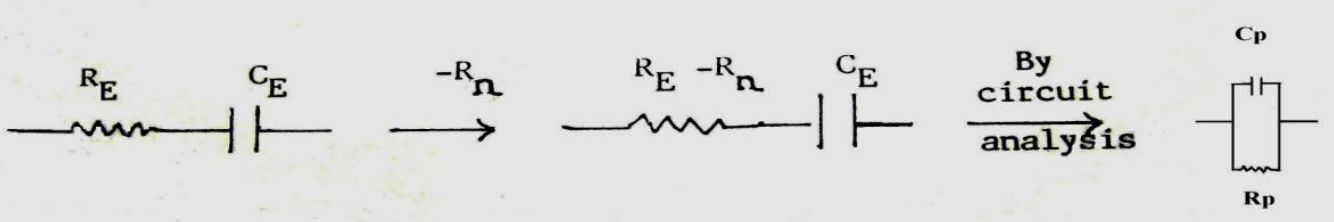

It is calculated using the following equations.

$\mathrm{R}_{\mathrm{p}}=\mathrm{R}^{\prime}{ }_{\mathrm{E}}[1+\mathrm{w}] / \mathrm{w} ; \mathrm{C}_{\mathrm{p}}=\left[\mathrm{C}_{\mathrm{E}} / \mathrm{A}\right] /[1+\mathrm{w}]$

Where $\mathrm{R}^{\prime}{ }_{\mathrm{E}}=\mathrm{R}_{\mathrm{E}}-\mathrm{R}_{\Omega}$ and $\mathrm{w}=\left[\omega \cdot \mathrm{R}_{\mathrm{E}} \cdot \mathrm{C}_{\mathrm{E}}\right]^{2}$

Both the methods were attempted and identical results were obtained. For all the four concentrations of Thallium(I) plots are made in the same plot. As $\omega^{-1} \rightarrow 0$, all the four plots tend to come closer and intercept at the same point on the $\mathrm{C}_{\mathrm{p}}$ axis.

(C) CNCS, Mekelle University 
From electrode admittance plots:

If $\mathrm{C}_{\mathrm{d}}$ remains constant $\mathrm{Y}^{\prime}{ }_{\text {el }} \mathrm{Vs}_{\mathrm{S}} \mathrm{Y}^{\prime}$ el plot will result in a straight line., the slope yielding the value of ' $\mathrm{p}$ ' and intercept that of $\mathrm{C}_{\mathrm{d}}$. The plot of $\mathrm{Y}$ '" ${ }_{\mathrm{el}} / \omega \mathrm{Vs} \mathrm{Y}_{\mathrm{el}} / \omega$ will also result in a straight line and $\mathrm{C}_{\mathrm{d}}$ can be obtained from intercept. In the $\mathrm{Y}^{\prime}{ }_{\text {el }} \mathrm{Vs}$ depolarizer concentration plot, $\omega \mathrm{C}_{\mathrm{d}}$ can be obtained from the intercept upon extrapolation to zero concentration. Calculation of $\Theta_{\mathrm{m}}$ and $\sigma_{\mathrm{m}}$ : Charge transfer resistance and the Warburg coefficient at the peak potential $\left(\Theta_{\mathrm{m}}, \sigma_{\mathrm{m}}\right)$ were obtained from $\mathrm{Z}_{\mathrm{f}}$ and $\mathrm{Z}$ "' ${ }_{\mathrm{f}}$ plot. The real and imaginary components of faradaic impedance are related to faradaic admittance by the following equations. $\mathrm{Y}_{\mathrm{f}}{ }_{\mathrm{f}}=\mathrm{y}{ }_{\mathrm{el}} ; \quad \mathrm{Y}^{\prime}{ }_{\mathrm{f}}=\mathrm{Y}^{\prime}{ }_{\mathrm{el}}-\omega \mathrm{C}_{\mathrm{d}}$; $Z_{\mathrm{f}}=\mathrm{Y}_{\mathrm{f}} /\left[\mathrm{Y}_{\mathrm{f}}{ }^{2}+\mathrm{Y}^{\prime}{ }_{\mathrm{f}}{ }^{2}\right] ; \quad \mathrm{Z}{ }^{\prime}{ }_{\mathrm{f}}=\mathrm{Y}{ }^{\prime}{ }_{\mathrm{f}}=\left[\mathrm{Y}_{\mathrm{f}}{ }^{2}+\mathrm{Y}^{\prime}{ }_{\mathrm{f}}^{2}\right] ; \mathrm{Z}_{\mathrm{f}}=\Theta+\sigma \omega^{-1 / 2} ; \quad \mathrm{Z}{ }_{\mathrm{f}}=\sigma \omega^{-1 / 2}$, Therefore a plot of $Z_{\mathrm{f}} \mathrm{Vs}^{-1 / 2}$ will yield a straight line and on extrapolation, $\Theta_{\mathrm{m}}$ can be obtained from intercept and $\sigma_{\mathrm{m}}$ from the slope. Plotting $Z{ }^{\prime}{ }_{\mathrm{f}} \mathrm{Vs} \omega^{-1 / 2}$ in the same plot will give a straight line parallel to $Z_{\mathrm{f}} \mathrm{Vs}^{-1 / 2}$ plot and passing through the origin. Thus both $\Theta_{\mathrm{m}}$ and $\sigma_{\mathrm{m}}$ can be obtained.

\section{RESULTS AND DISCUSSION}

\subsection{Polarography}

DC Polarograms of Thallium(I) in all the three supporting electrolytes were well defined and the $\mathrm{E}_{1 / 2}$ values are given in the (Table 1). For all the three systems $\mathrm{E}_{3 / 4}-\mathrm{E}_{1 / 4}$ was found to be $55 \mathrm{mV}$. The log plots resulted in a straight line and the slope value for all the systems were found to be $60 \mathrm{mV}$, which is the theoretical value corresponding to a single electron reversible reduction. The polarograms and the log plots are given in the figure 1. The shape of the polarograms and the slope values from the log-plot very clearly shows the reversible nature of reduction in all the three systems. The value of transfer coefficient, ' $\alpha$ ' was determined from the equation, $\mathrm{E}_{\mathrm{P}}=\mathrm{E}_{1 / 2}+[\mathrm{RT} / \mathrm{nF}] \ln [\alpha / 1-\alpha]$

Table1. DC Polarographic data and $\mathrm{E}_{\mathrm{P}}$ of Thallium(I)-Aqueous systems.

\begin{tabular}{|lccccc|}
\hline $\begin{array}{l}\text { Supporting } \\
\text { Electrolyte }\end{array}$ & $-E_{1 / 2}$ Volt & $\begin{array}{c}\text { Peak } \\
\text { potential }(\boldsymbol{V})\end{array}$ & $\begin{array}{c}\boldsymbol{E}_{3 / 4}-\boldsymbol{E}_{1 / 4} \\
(\boldsymbol{m} \boldsymbol{V})\end{array}$ & $\begin{array}{c}\text { Slope values } \\
(\boldsymbol{m} \boldsymbol{V})\end{array}$ & $\boldsymbol{A}$ \\
\hline $0.5 \mathrm{M} \mathrm{NaClO}_{4}$ & 0.485 & 0.485 & 55 & 60 & 0.5 \\
\hline $0.5 \mathrm{M} \mathrm{KNO}_{3}$ & 0.495 & 0.495 & 55 & 60 & 0.5 \\
\hline $0.5 \mathrm{M} \mathrm{KCl}$ & 0.500 & 0.500 & 55 & 60 & 0.5 \\
\hline
\end{tabular}


Since the peak potential was found to be equal to half wave potential, the value of transfer coefficient was found to be 0.5 in all the three systems. The values are provided in (Table 1).

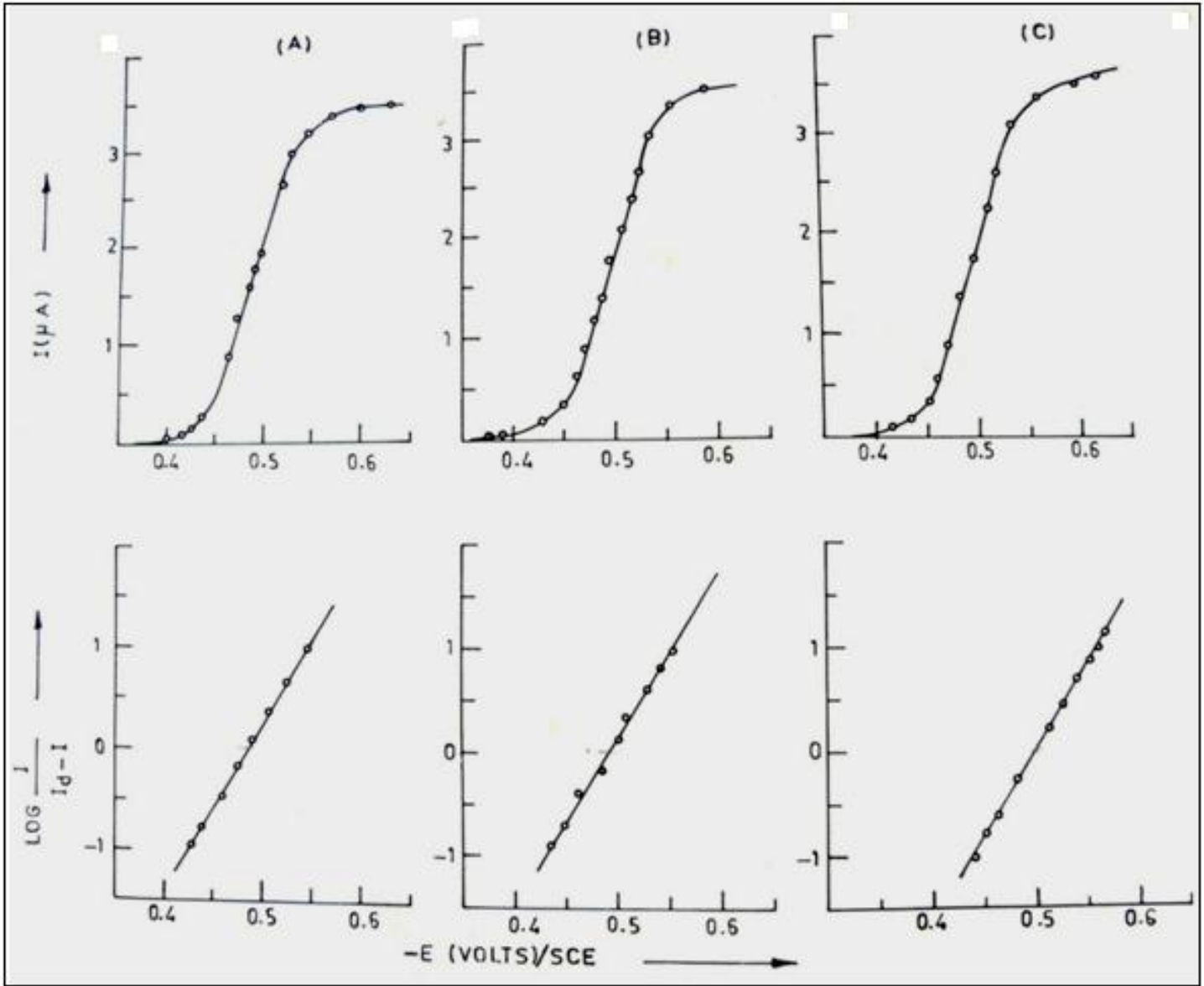

Figure 1. DC Polarograms and log plots of $\mathrm{Tl}^{+}$in (A) $0.5 \mathrm{M} \mathrm{NaClO}_{4}$; (B) $0.5 \mathrm{M} \mathrm{KNO}_{3}$; (C) $0.5 \mathrm{MKCl}$.

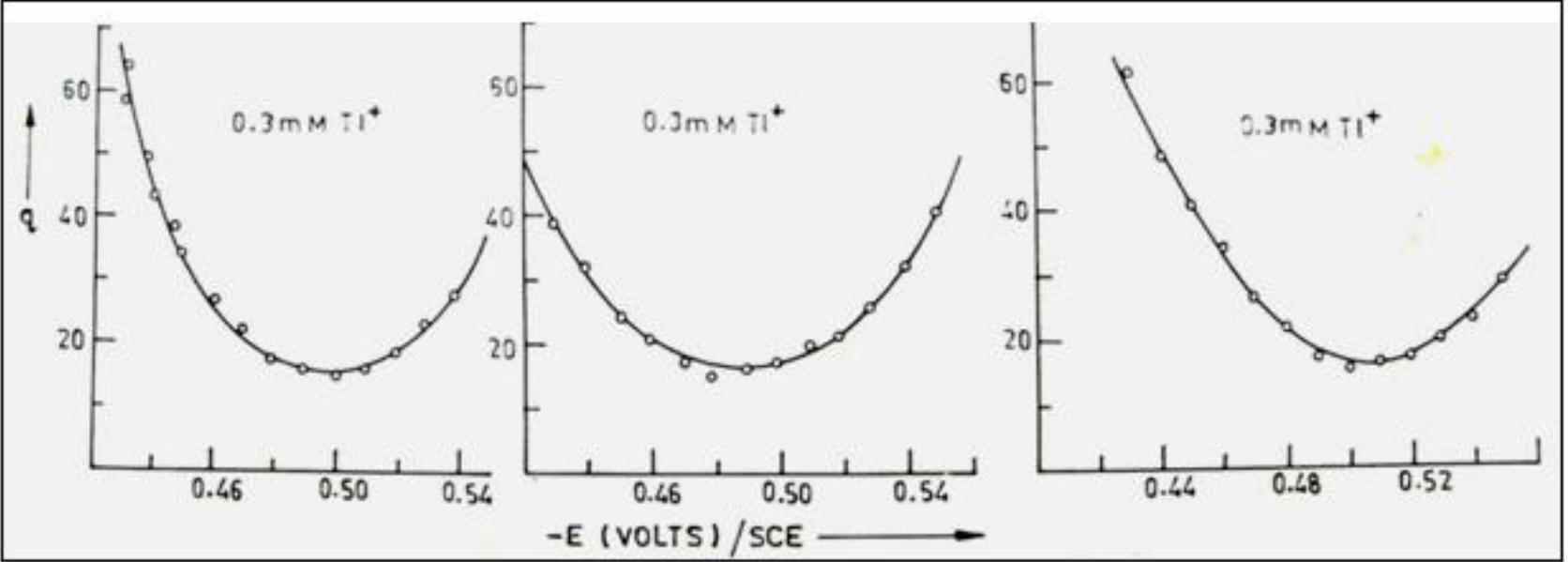

Figure 2. q Vs potential plots for $\mathrm{Tl}^{+}$in (A) $0.5 \mathrm{M} \mathrm{NaClO}_{4}$; (B) $0.5 \mathrm{M} \mathrm{KNO}_{3}$; (C) $0.5 \mathrm{M} \mathrm{KCl}$. 
Table 2. Potential variation method (0.3mM Thallium(I)- $0.5 \mathrm{M} \mathrm{NaClO}_{4} / \mathrm{KNO}_{3} / \mathrm{KCl}$ systems).

$1 . \mathrm{m}=2.143 \mathrm{mg} / \mathrm{sec} \quad \mathrm{t}=3.9 \mathrm{sec} \quad \mathrm{R}=2.33 \mathrm{ohm} . \mathrm{cm}^{2} \quad \mathrm{C}_{\mathrm{d}}=30 \mu \mathrm{F} / \mathrm{cm}^{2} \mathrm{f}=750 \mathrm{~Hz}$.

2. $\mathrm{m}=2.259 \mathrm{mg} / \mathrm{sec} \quad \mathrm{t}=3.7 \mathrm{sec} \quad \mathrm{R}=1.994 \mathrm{ohm} . \mathrm{cm}^{2} \quad \mathrm{C}_{\mathrm{d}}=32 \mu \mathrm{F} / \mathrm{cm}^{2} \mathrm{f}=750 \mathrm{~Hz}$.

3. $\mathrm{m}=2.143 \mathrm{mg} / \mathrm{sec} \quad \mathrm{t}=3.9 \mathrm{sec} \quad \mathrm{R}=1.959 \mathrm{ohm} . \mathrm{cm}^{2} \quad \mathrm{C}_{\mathrm{d}}=40 \mu \mathrm{F} / \mathrm{cm}^{2} \quad \mathrm{f}=750 \mathrm{~Hz}$.

\begin{tabular}{|c|c|c|c|c|c|c|c|c|c|}
\hline \multicolumn{3}{|c|}{ (1) $0.5 \mathrm{M} \mathrm{NaClO} \mathrm{N}_{4}$} & \multicolumn{3}{|c|}{ (2) $0.5 \mathrm{M} \mathrm{KNO}$} & \multicolumn{3}{|c|}{ (3) $0.5 \mathrm{M} \mathrm{KCl}$} & \multirow[b]{2}{*}{$q$} \\
\hline$-E$ (Volt) & $Z^{\prime}$ & $Z^{\prime \prime}$ & $q$ & $Z^{\prime}$ & $Z^{\prime \prime}$ & $q$ & $Z^{\prime}$ & $Z^{\prime \prime}$ & \\
\hline 0.420 & 3.15 & 6.19 & 48.3 & 2.55 & 6.34 & 72.52 & 2.20 & 4.73 & 36.09 \\
\hline 0.430 & 3.32 & 6.08 & 38.76 & 2.66 & 6.19 & 72.45 & 2.31 & 4.61 & 27.05 \\
\hline 0.440 & 3.50 & 5.85 & 30.74 & 2.66 & 5.94 & 48.72 & 2.38 & 4.47 & 21.65 \\
\hline 0.450 & 3.67 & 5.30 & 22.47 & 2.87 & 5.71 & 38.14 & 2.45 & 4.39 & 18.64 \\
\hline 0.460 & 3.74 & 5.05 & 19.62 & 3.11 & 5.26 & 25.87 & 2.52 & 4.32 & 16.25 \\
\hline 0.470 & 3.85 & 4.64 & 15.81 & 3.18 & 5.05 & 17.14 & 2.62 & 4.12 & 12.79 \\
\hline 0.480 & 3.85 & 4.58 & 15.46 & 3.36 & 4.64 & 17.14 & 2.73 & 3.95 & 10.39 \\
\hline 0.490 & 3.78 & 4.64 & 16.44 & 3.39 & 4.50 & 15.86 & 2.80 & 3.75 & 8.70 \\
\hline 0.500 & 3.71 & 4.73 & 17.74 & 3.39 & 4.42 & 15.35 & 2.87 & 3.62 & 7.63 \\
\hline 0.510 & 3.64 & 4.85 & 19.47 & 3.32 & 4.47 & 16.37 & 2.83 & 3.66 & 8.02 \\
\hline 0.520 & 3.57 & 4.92 & 20.96 & 3.22 & 4.55 & 18.16 & 2.80 & 3.69 & 8.43 \\
\hline 0.530 & 3.50 & 5.38 & 26.21 & 3.15 & 4.70 & 20.27 & 2.80 & 3.69 & 8.42 \\
\hline 0.540 & 3.39 & 5.71 & 32.11 & 3.08 & 4.98 & 23.96 & 2.66 & 3.95 & 11.08 \\
\hline 0.550 & 3.25 & 5.94 & 39.67 & 3.01 & 5.30 & 28.72 & 2.59 & 4.24 & 14.29 \\
\hline
\end{tabular}

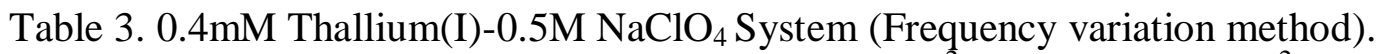

$\mathrm{m}=2.143 \mathrm{mg} / \mathrm{sec} \quad \mathrm{t}=3.9 \mathrm{sec} . \quad \mathrm{R}_{\Omega}=2.34 \mathrm{Ohm} . \mathrm{cm}^{2} \quad \mathrm{C}_{\mathrm{d}}=30 \mu \mathrm{F} / \mathrm{cm}^{2} \quad \mathrm{E}_{\mathrm{p}}=-0.485 \mathrm{~V}$

\begin{tabular}{|lcccccccc|}
\hline Frequency & $\boldsymbol{Z}^{\prime}$ & $\boldsymbol{Z}^{\prime \prime}$ & $\boldsymbol{C}_{\boldsymbol{p}}$ & $\boldsymbol{Y}^{\prime}{ }_{e l}$ & $\boldsymbol{Y}^{\prime \prime}{ }_{e l}$ & $\boldsymbol{Y}^{\prime \prime}{ }_{f}$ & $\mathbf{Z}_{f}$ & $\mathbf{Z}^{\prime \prime}$ \\
\hline 400 & 4.97 & 6.63 & 51.88 & 0.052 & 0.13 & 0.055 & 9.07 & 9.66 \\
\hline 500 & 4.65 & 5.80 & 47.36 & 0.059 & 0.15 & 0.057 & 9.13 & 8.41 \\
\hline 600 & 4.27 & 4.99 & 46.27 & 0.067 & 0.17 & 0.061 & 8.11 & 7.40 \\
\hline 700 & 4.09 & 4.37 & 44.83 & 0.079 & 0.20 & 0.065 & 7.53 & 6.22 \\
\hline 800 & 3.88 & 4.09 & 42.56 & 0.080 & 0.21 & 0.063 & 7.69 & 6.03 \\
\hline 900 & 3.60 & 3.75 & 42.37 & 0.081 & 0.24 & 0.070 & 7.08 & 6.15 \\
\hline 1000 & 3.39 & 3.52 & 41.47 & 0.078 & 0.26 & 0.072 & 6.92 & 6.42 \\
\hline 1200 & 3.25 & 2.99 & 40.55 & 0.093 & 0.31 & 0.080 & 6.21 & 5.31 \\
\hline 1400 & 3.15 & 2.60 & 39.90 & 0.109 & 0.35 & 0.087 & 5.60 & 4.49 \\
\hline 1600 & 3.04 & 2.32 & 39.29 & 0.119 & 0.40 & 0.093 & 5.20 & 4.07 \\
\hline 1800 & 2.94 & 2.10 & 38.90 & 0.124 & 0.44 & 0.101 & 4.86 & 3.93 \\
\hline 2000 & 2.83 & 1.99 & 37.72 & 0.117 & 0.47 & 0.097 & 5.07 & 4.21 \\
\hline 2500 & 2.76 & 1.64 & 36.47 & 0.147 & 0.57 & 0.102 & 4.60 & 3.18 \\
\hline 3000 & 2.69 & 1.40 & 35.76 & 0.169 & 0.67 & 0.109 & 4.19 & 2.69 \\
\hline 4000 & 2.62 & 1.07 & 34.77 & 0.229 & 0.87 & 0.120 & 4.43 & 1.80 \\
\hline 5000 & 2.55 & 0.95 & 31.89 & 0.221 & 1.00 & 0.059 & 4.22 & 1.13 \\
\hline 10000 & 2.45 & 0.50 & 30.64 & 0.407 & 1.93 & 0.040 & 2.44 & 0.24 \\
\hline
\end{tabular}




\subsection{Complex plane Polarography}

Potential variation experiments were carried out at a fixed frequency of $750 \mathrm{~Hz}$ in the potential range corresponding to the rising portion of the wave in DC polarogram for all the respective systems and the q Vs potential plots were drawn and given in figure 2. The Experimental values for all the systems are given in (Table 2). The minimum of the curves corresponds to the peak potential (Table 1).

Frequency variation experiments were carried out at the respective peak potentials for all the systems. The experimental values with other calculated parameters are given for $0.4 \mathrm{mM}$ Thallium(I)- $0.5 \mathrm{M} \mathrm{NaClO}_{4}$ only for want of space in (Table 3). The mass and drop time of mercury are provided on the top of the table.

\subsection{Series resistance}

The series resistance $\mathrm{R}_{\Omega}$ was calculated for all systems by the three methods described above. It is quite remarkable that the values determined by the three different methods are in fair agreement. The series resistance is provided along with the data for the frequency variation experiments. The plots for Thallium(I)-0.5 $\mathrm{M} \mathrm{NaClO}_{4}$ are given in figure 3. The plots are similar for other systems.

\subsection{Determination of double layer capacity}

1. $\mathbf{C}_{\mathrm{P}}$ Vs $\omega^{-1}$ Plots: The plots are given in the figures 4 and 5 for all the three systems. For a given system the plots for four different concentrations of Thallium (I) were drawn on the same plot (fig.4). In the case of Thallium(I)-0.5 $\mathrm{M} \mathrm{NaClO}_{4}$ system, at higher values of $\omega^{-1}, \mathbf{C}_{\mathrm{P}}$ was found to be concentration dependent. As $\omega^{-1} \rightarrow 0$, all the four plots tend to become closer and intercept at the same point. This shows that the double layer capacity is independent of depolarizer concentration and the $C_{d}$ is found to be $30 \mu \mathrm{F} / \mathrm{cm}^{2}$.

For the systems, Thallium(I)- $0.5 \mathrm{M} \mathrm{KNO}_{3}$ and Thallium (I)- $0.5 \mathrm{M} \mathrm{KCl}$ at higher values of $\omega^{-1}, \mathbf{C}_{\mathrm{P}}$ was found to be concentration dependent. This behavior persists and becomes permanent even when $\omega^{-1} \rightarrow 0$. The plots of four different concentrations make four different intercepts. This fact shows that $\mathrm{C}_{\mathrm{d}}$ is dependent on the concentration of the depolarizer. $\mathrm{C}_{\mathrm{d}}$ values are reported in (Table 4).

2. Y' ${ }^{\prime}$ el Vs Y ${ }_{\text {el }}$ Plots: These plots for different concentrations of the depolarizer at fixed frequency are given in figures 5 . If $\mathrm{C}_{\mathrm{d}}$ remains constant, a plot of $\mathrm{Y}^{\prime}$, ${ }_{\text {elagainst }} \mathrm{Y}^{\prime}$ el will result in a straight line and the slope gives the value of $\mathrm{C}_{\mathrm{d}}$. This method is not principally 
different from that of Z'-Z' plane which was originally used but it is easier to handle and its relation to the theory is more direct (Sluyters-Rehbach and Sluyter, 1963a\&b). The $\mathrm{C}_{\mathrm{d}}$ obtained in this mode of analysis was found to be $30 \mu \mathrm{F} / \mathrm{cm}^{2}$ for the Thallium (I)- $0.5 \mathrm{M}$ $\mathrm{NaClO}_{4}$ system. For the systems, Thallium(I)-0.5M KNO 3 and Thallium(I)-0.5M KCl the $\mathrm{C}_{\mathrm{d}}$ has already been found to be dependent on depolarizer concentration. This plot is expected to give only the $\mathrm{C}_{\mathrm{d}}$ of the blank solution. The values are tabulated (Table.4).

3. $\mathrm{Y}^{\prime}{ }_{\mathrm{el}} / \omega \mathrm{Vs} \mathrm{Y}^{\prime}{ }_{\mathrm{el}} / \omega$ Plots with different depolarizer concentrations at fixed frequencies: In this plot $\mathrm{C}_{\mathrm{d}}$ will be obtained by extrapolation to zero admittance which is practically equal to zero metal ion concentration. In general such plots will give the double layer capacity of the blank solution. Y' ${ }^{\prime}$ el Vs depolarizer concentration plot is also similar to this. Therefore, such plots are not attempted for the systems whose $C_{d}$ depends on the concentration of the depolarizer. The values are tabulated(Table.4).

4. Y" ${ }_{\text {el }}$ Vs depolarizer concentration plot: This plot was drawn only for Thallium (I)-0.5M $\mathrm{NaClO}_{4}$ system. The intercept gives $\omega \mathrm{C}_{\mathrm{d}}$. Such plots for various frequencies are given in figure . The value has been found to be $30 \mu \mathrm{F} / \mathrm{cm}^{2}$. At the same peak potential, $\mathrm{C}_{\mathrm{d}}$ of the blank solution (test solution without depolarizer) was also determined and tabulated (Table.4).

Table 4. Double layer capacity from various methods $-\mathrm{C}_{\mathrm{d}} \mu \mathrm{F} / \mathrm{cm}^{2}$.

\begin{tabular}{|c|c|c|c|c|c|}
\hline $\begin{array}{l}\text { Supporting } \\
\text { Electrolyte }\end{array}$ & $\begin{array}{l}C_{P} V_{S} \omega^{-1} \\
\text { plot }\end{array}$ & 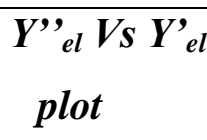 & $\begin{array}{c}Y_{e l}^{\prime \prime} / \omega V_{S} Y_{e l}^{\prime} / \omega \\
\text { plot }\end{array}$ & $\begin{array}{r}Y{ }_{e l} \text { Vs Conc. } \\
\text { plot }\end{array}$ & $C_{d}$ of blank \\
\hline $0.5 \mathrm{M} \mathrm{NaClO}_{4}$ & $4 \quad 30$ & 30 & 30 & 30 & 27.9 \\
\hline \multicolumn{6}{|c|}{$0.5 \mathrm{MKNO}_{3} \quad\left(0.3 \mathrm{Mm} \mathrm{Tl}^{+}\right) 32$} \\
\hline \multicolumn{6}{|c|}{$\left(0.4 \mathrm{Mm} \mathrm{Tl}^{+}\right) 33$} \\
\hline \multicolumn{6}{|c|}{$\left(0.5 \mathrm{Mm} \mathrm{Tl}^{+}\right) 34$} \\
\hline \multicolumn{6}{|c|}{$\left(0.6 \mathrm{Mm} \mathrm{Tl}^{+}\right) 35$} \\
\hline \multirow[t]{4}{*}{$0.5 \mathrm{MKCl}$} & $\left(0.3 \mathrm{Mm} \mathrm{Tl}^{+}\right) 40$ & & & & \\
\hline & $\left(0.4 \mathrm{Mm} \mathrm{Tl}^{+}\right) 42$ & & & & \\
\hline & $\left(0.5 \mathrm{Mm} \mathrm{Tl}^{+}\right) 44$ & 36 & -- & -- & 36 \\
\hline & $\left(0.6 \mathrm{Mm} \mathrm{Tl}^{+}\right) 46$ & & & & \\
\hline
\end{tabular}


Table 5. $\Theta_{\mathrm{m}} \mathrm{C}, \sigma_{\mathrm{m}} \mathrm{C}$ and $\mathrm{K}_{\mathrm{s}, \mathrm{h}}$ values of different systems.

\begin{tabular}{|lccccc|}
\hline $\begin{array}{l}\text { Supporting } \\
\text { Electrolyte }\end{array}$ & $\begin{array}{c}\text { Conc. } \boldsymbol{O f} \\
\boldsymbol{T l}^{+}(\boldsymbol{m} \boldsymbol{M})\end{array}$ & $\boldsymbol{\Theta}_{\boldsymbol{m}} \boldsymbol{C}$ & $\boldsymbol{\sigma}_{\boldsymbol{m}} \boldsymbol{C}$ & $\begin{array}{c}\text { Average } \\
\boldsymbol{\Theta}_{\boldsymbol{m}} \boldsymbol{C}\end{array}$ & $\begin{array}{c}\boldsymbol{K}_{\boldsymbol{s}, \boldsymbol{h}} \\
\boldsymbol{c m} / \mathbf{s e c}\end{array}$ \\
\hline $0.5 \mathrm{M} \mathrm{NaClO}_{4}$ & 0.3 & 0.39 & 173 & & \\
& 0.4 & 0.40 & 184 & 0.403 & 1.345 \\
& 0.5 & 0.40 & 215 & & \\
& 0.6 & 0.42 & 192 & & \\
$0.5 \mathrm{MKNO}_{3}$ & 0.3 & 0.36 & 173 & & \\
& 0.4 & 0.36 & 180 & 0.358 & 1.514 \\
& 0.5 & 0.35 & 175 & & \\
& 0.6 & 0.36 & 168 & & \\
$0.5 \mathrm{MKCl}^{-5}$ & 0.3 & 0.33 & 132 & & \\
& 0.4 & 0.32 & 156 & 0.340 & \\
& 0.5 & 0.35 & 160 & & \\
& 0.6 & 0.36 & 162 & & \\
\hline
\end{tabular}

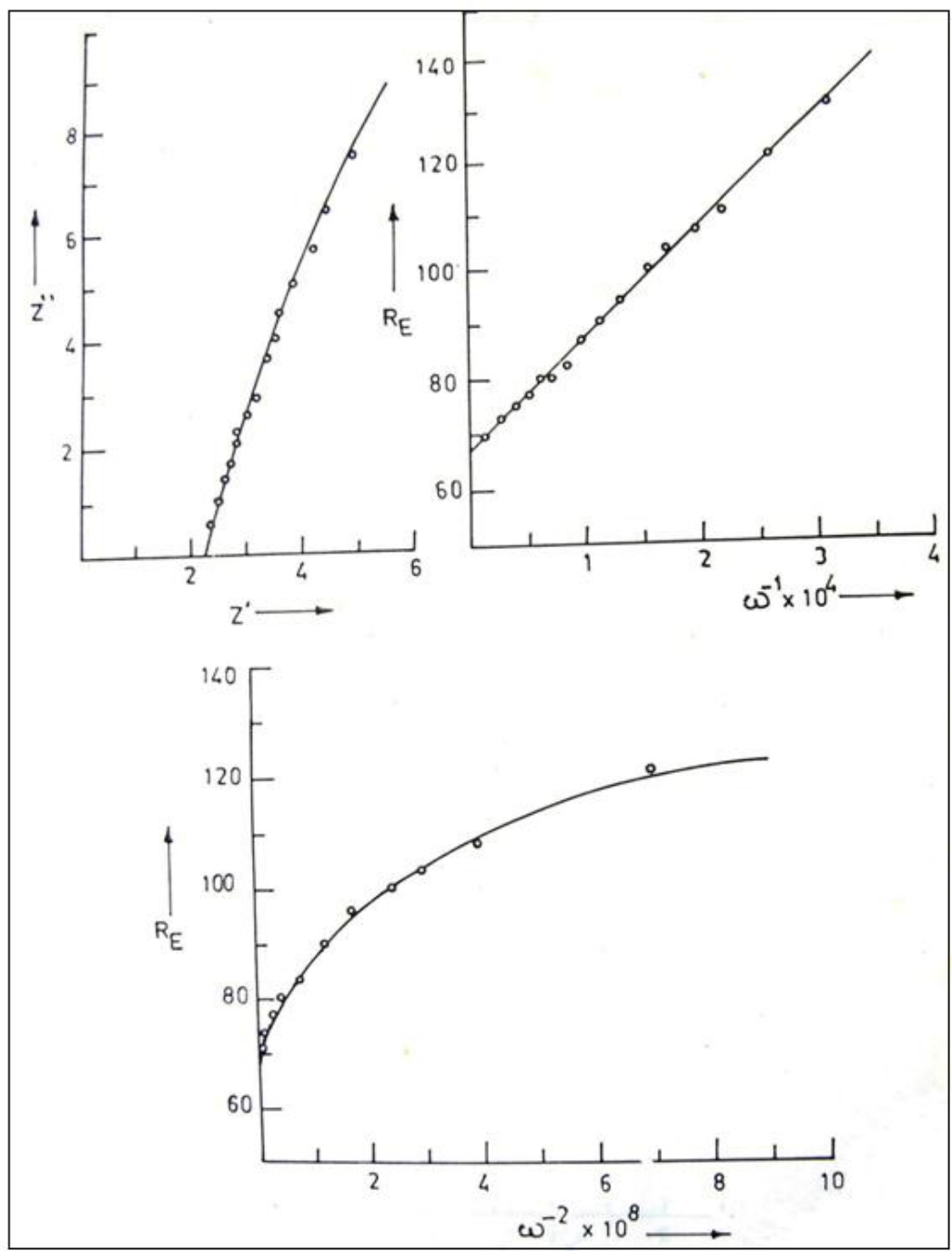

Figure 3. Plots for determination of series resistance $\mathrm{R}_{\Omega}$. 


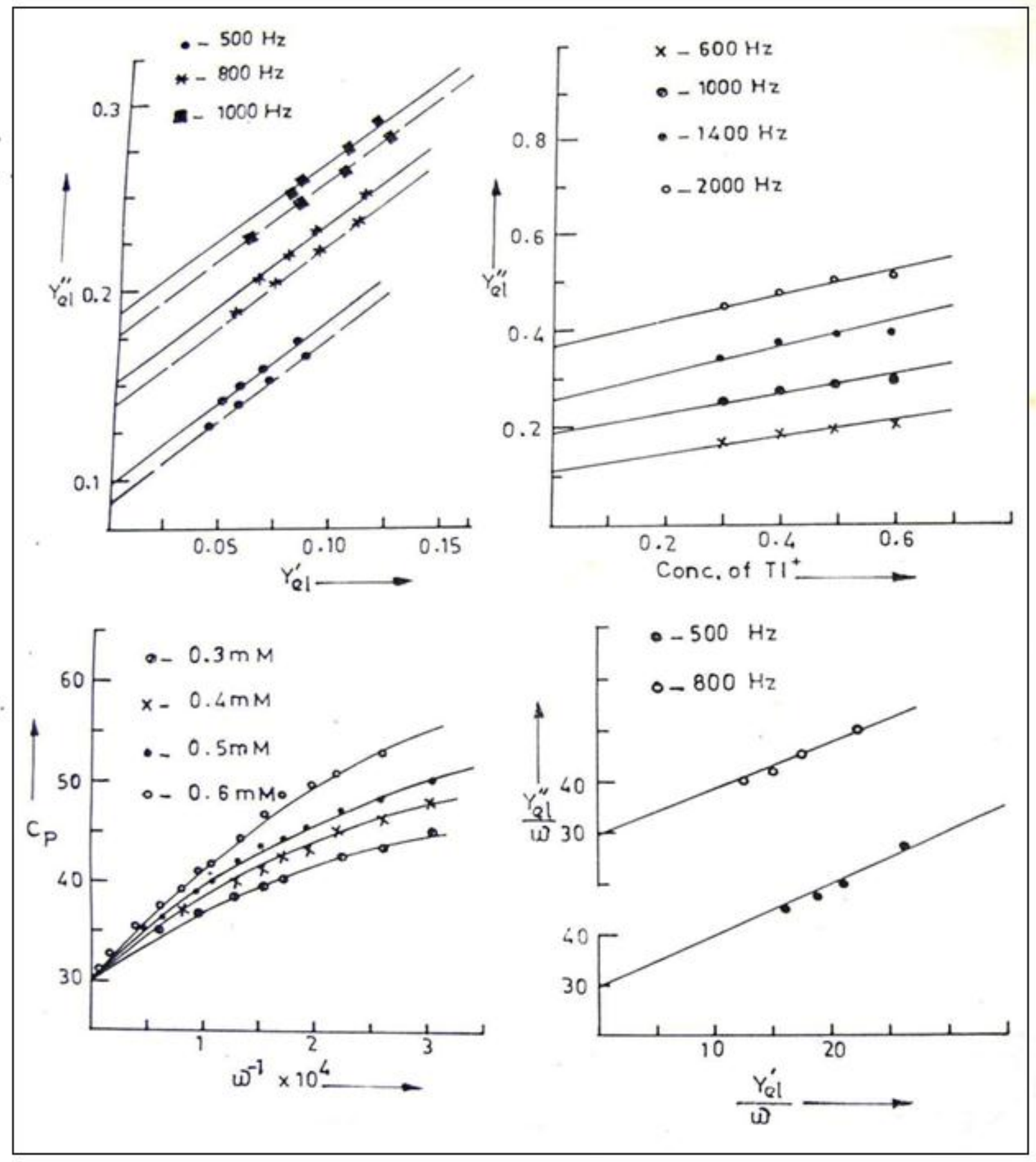

Figure 4. Determination of double layer capacity of Thallium(I)- $0.5 \mathrm{M} \mathrm{NaClO} \mathrm{S}_{4}$ System. 


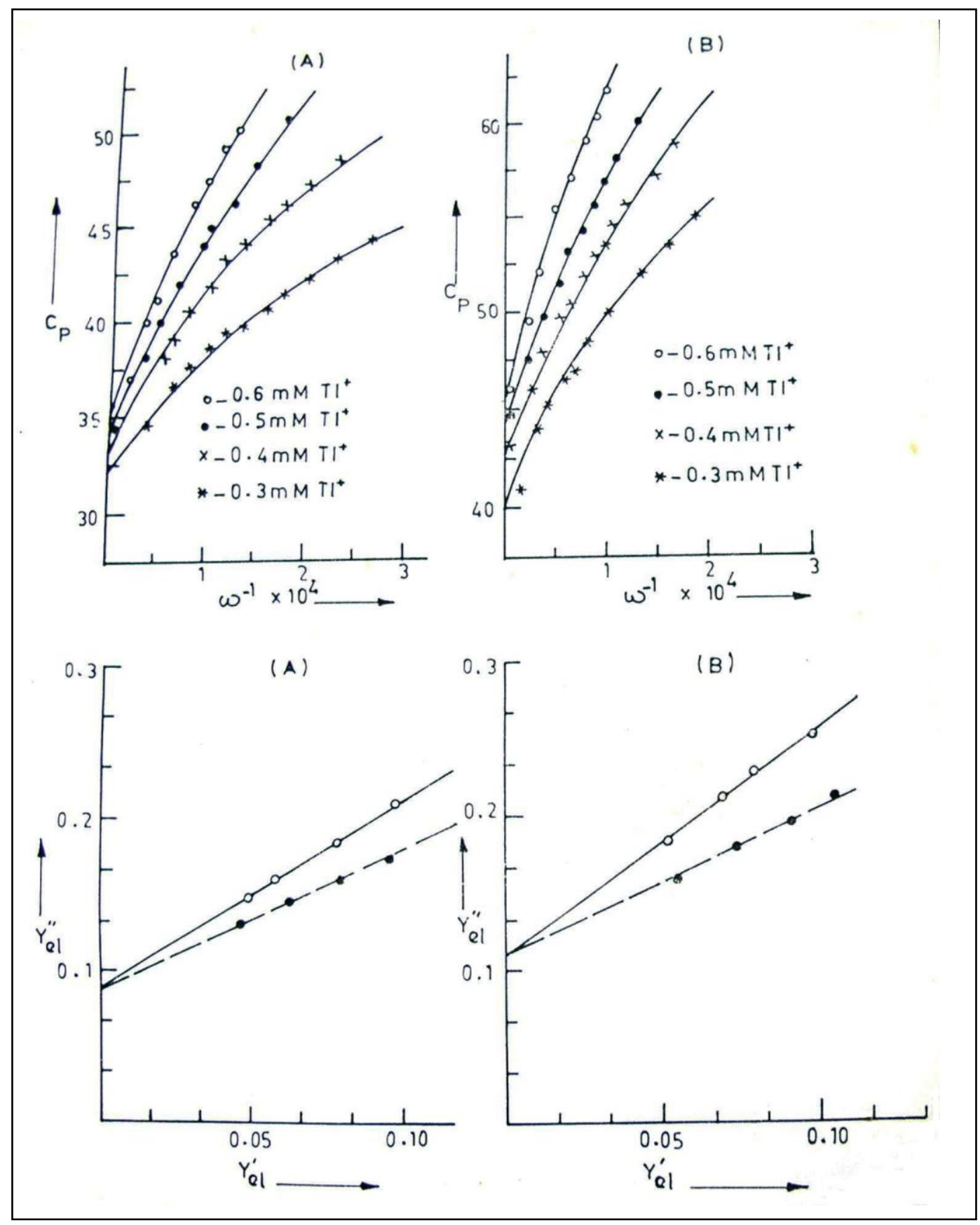

Figure 5. Double layer capacity of $\mathrm{Tl}^{+}$in (A) $0.5 \mathrm{M} \mathrm{KNO}_{3}$ and (B) $0.5 \mathrm{M} \mathrm{KCl}$.

\subsection{Determination of $\Theta_{m}$ and $\sigma_{m}$ at the peak potentials}

The real and imaginary components of faradaic impedance, $Z_{\mathrm{f}}$ and $\mathrm{Z}{ }^{\prime}{ }_{\mathrm{f}}$ as described earlier. were drawn against $\omega^{-1 / 2}$ in the same plot. The plot of $Z^{\prime}{ }_{\mathrm{f}} \mathrm{Vs} \omega^{-1 / 2}$ must result in a straight line and pass through the origin and the plot of $Z_{\mathrm{f}} \mathrm{Vs}^{-1 / 2}$ must be parallel to that and make an intercept. In the case of Thallium (I)- $0.5 \mathrm{M} \mathrm{NaClO}_{4}$ system, computation of $\mathrm{Z}_{\mathrm{f}}$ and $\mathrm{Z}^{\prime}{ }_{\mathrm{f}}$ using (C) CNCS, Mekelle University

ISSN: 2220-184X 
the $\mathrm{C}_{\mathrm{d}}$ of the blank solution show that $\mathrm{Z}_{\mathrm{f}}$ is almost equal to $\mathrm{Z}^{\prime}{ }_{\mathrm{f}}$ at certain frequencies and even lower at other frequencies. So, $\Theta_{\mathrm{m}}$ cannot be extracted from the plots. The computation of $Z^{\prime}{ }_{f}$ and $Z$ " ${ }_{\mathrm{f}}$ using the $\mathrm{C}_{\mathrm{d}}$ value obtained from the extrapolation method show that the values of $Z_{f}$ are greater than $Z{ }^{\prime}{ }_{f}$ in the entire frequency range and thereby makes the way for the determination of $\Theta_{\mathrm{m}}$ and $\sigma_{\mathrm{m}}$. Relevant plots are given in the fig 6 and values are provided in (Table.5)

In Thallium (I)- $0.5 \mathrm{M} \mathrm{KNO}_{3}$ and Thallium(I)- $0.5 \mathrm{M} \mathrm{KCl}$ systems also, the computation of $\mathrm{Z}_{\mathrm{f}}$ and $\mathrm{Z}$ ' ${ }_{\mathrm{f}}$ using the $\mathrm{C}_{\mathrm{d}}$ of the blank solution show that $\mathrm{Z}_{\mathrm{f}}$ is lower than $\mathrm{Z}{ }_{\mathrm{f}}$ values at all frequency range. The computation of $Z_{\mathrm{f}}$ and $Z^{\prime}{ }_{\mathrm{f}}$ using the $\mathrm{C}_{\mathrm{d}}$ value obtained from the extrapolation method for every concentration of the depolarizer gives values of $Z{ }^{\prime}{ }_{f}$ greater than that of $Z$ ' ${ }_{f}$ values. The values of $\Theta_{\mathrm{m}}$ and $\sigma_{\mathrm{m}}$ (Table.5) were easily extracted from the plots. figure 7 and 8

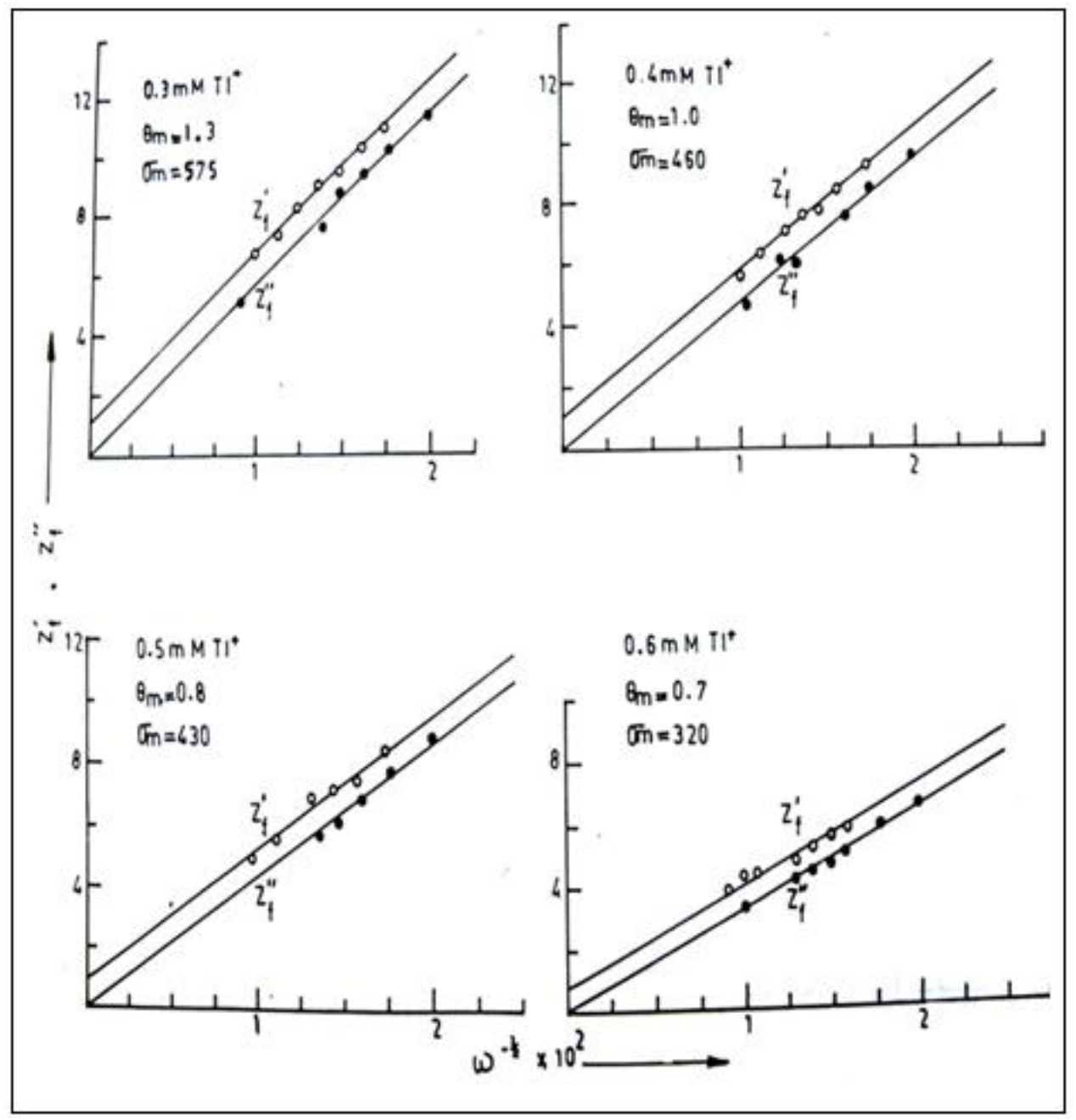

Figure. 6. Z' Vs Z" plots of Thallium(I)-0.5M NaClO 4 System. 


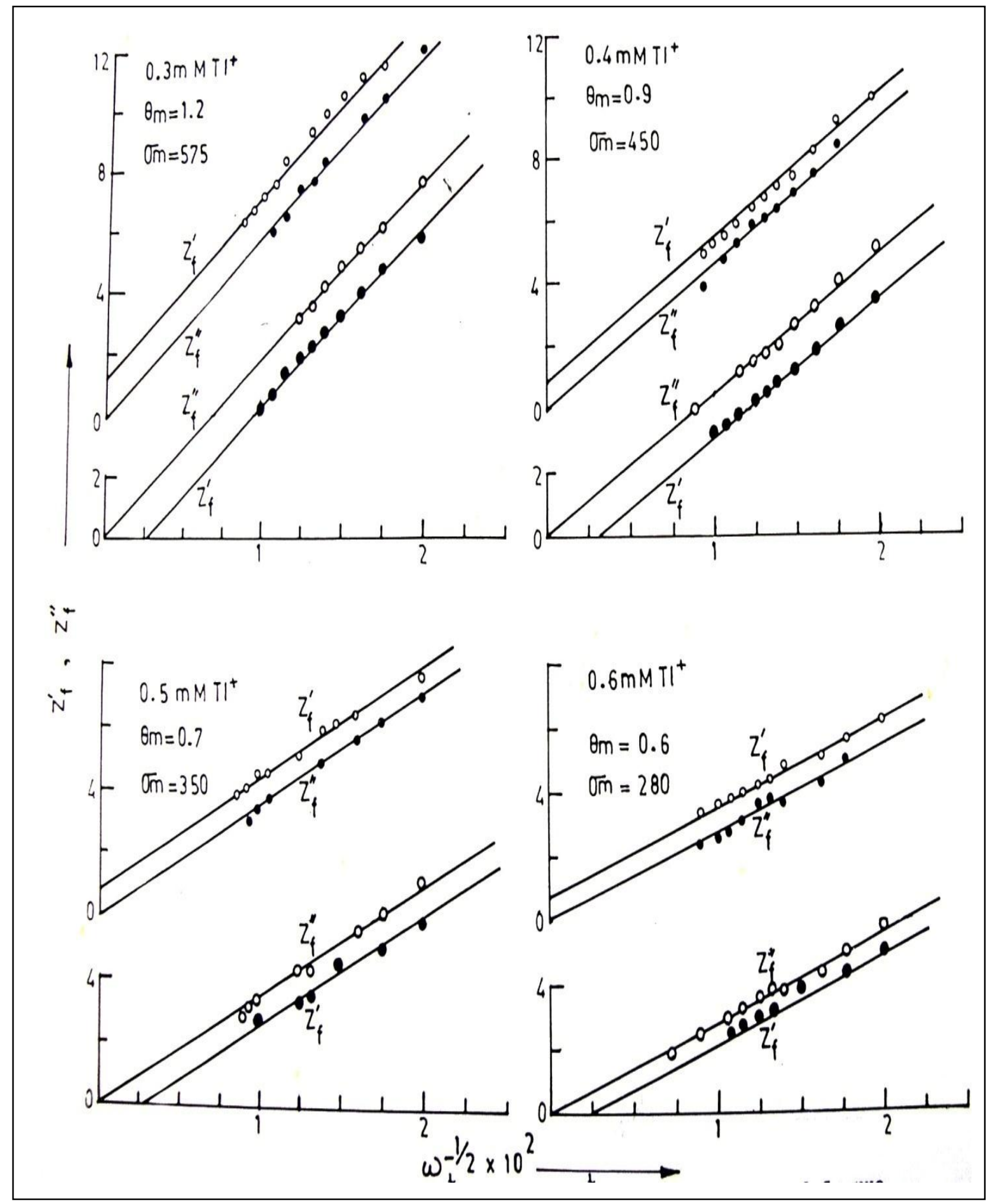

Figure7. Z' Vs Z' plots of Thallium(I)-0.5M KNO 3 System. 


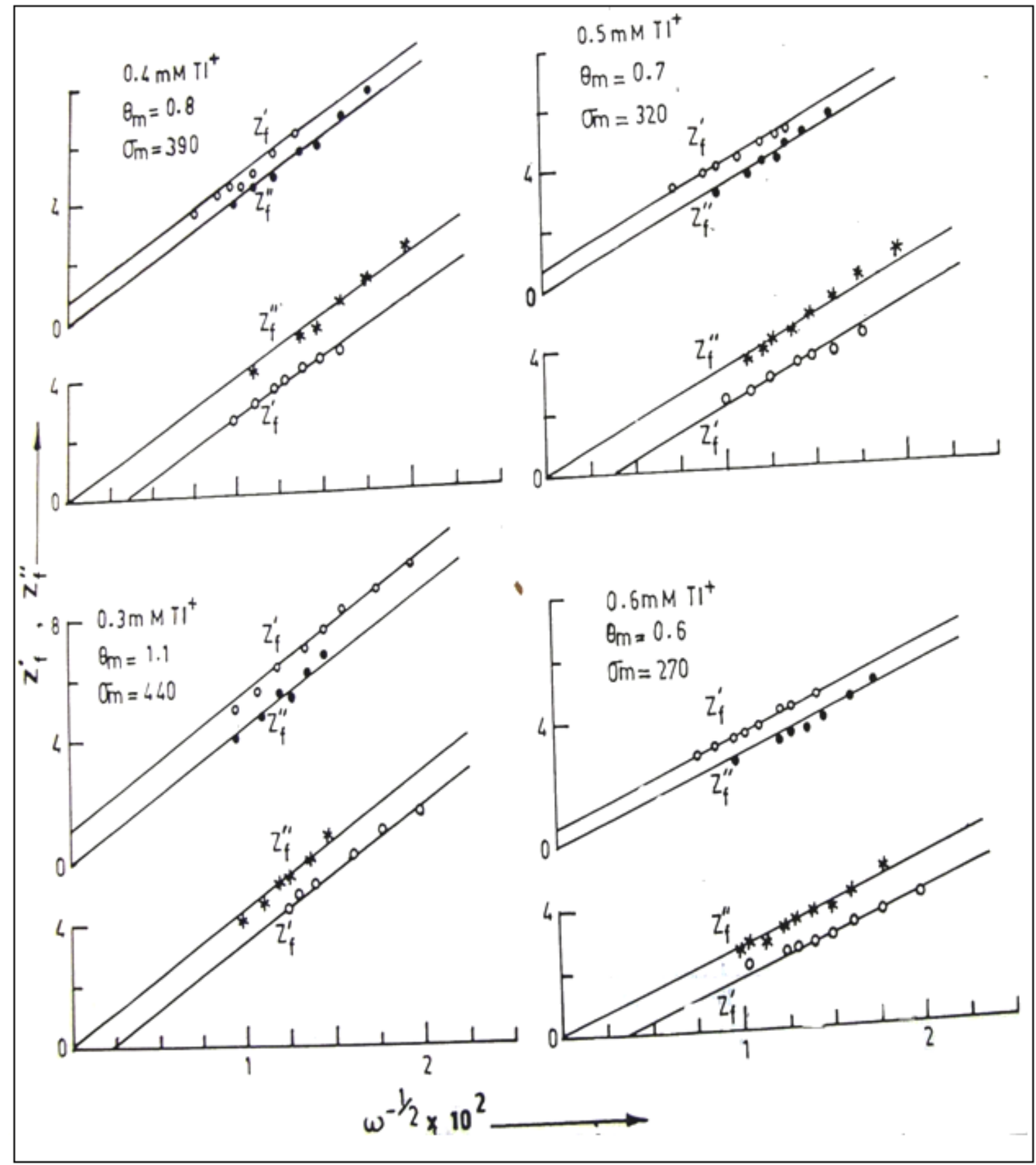

Figure 8. Z' Vs Z'” plots of Thallium(I)-0.5M KCl System.

\subsection{Phase sensitive ac Polarograms}

$\mathrm{Y}_{\text {el }} \mathrm{Vs} \mathrm{E}$ plot is representative of the ideal 'inphase' ac polarogram with hypothetically the series resistance, $\mathrm{R}_{\Omega}=0 . \mathrm{Y}^{\prime}{ }_{\text {el }} \mathrm{Vs} \mathrm{E}$ plot resembles the 'quadrature' ac polarograms. These phase sensitive ac polarograms are well formed for Thallium(I)-0.5 $\mathrm{M} \mathrm{NaClO}_{4}$ system indicating the (C) CNCS, Mekelle University 
reversibility of the reduction process. In order to have better appreciation of the use of these phase sensitive polarograms for drawing conclusions regarding the nature of reversibility and adsorption, theoretical plots have been made for the rate constant corresponding to $0.3 \mathrm{mM}$ concentration of $\mathrm{Tl}(\mathrm{I})$. For this theoretical plots equations given by Timmer et al. (1968a); Sluyters-Rehbach et al. (1964); and Sluyters-Rehbach and Sluyters (1970) were used. The various parameters given as inputs for the equations are as follows.

Number of electrons involved, $\mathrm{n}=1 ; \mathrm{T}=303 \mathrm{~K} ; \mathrm{f}=750 \mathrm{~Hz}$; Anodic transfer coefficient, $\alpha=$ 0.5 ; time, $\mathrm{t}=3.5 \mathrm{sec}$; $\mathrm{F}=96500$ coulombs.

Concentration of oxidant, $\mathrm{C}_{0}=0.3 \mathrm{mM}$; concentration of reductant, $\mathrm{C}_{\mathrm{R}}=0$; diffusion coefficient, $\mathrm{D}_{0}=1.97 \times 10^{-5} \mathrm{Cm}^{2} / \mathrm{sec} ;$ Rate constant, $\mathrm{K}_{\mathrm{s}, \mathrm{h}}=1.39 \mathrm{~cm} / \mathrm{sec} ; \mathrm{C}_{\mathrm{d}}=27.9 \mu \mathrm{f} / \mathrm{cm}^{2}$

The $\mathrm{C}_{\mathrm{d}}$ of the blank is used and this will not vary very much in the potential range in which calculations are made. The plots are given in figure9.The experimental and theoretical plots agree well with each other in the case of $\mathrm{Y}^{\prime}{ }_{\mathrm{el}} \mathrm{Vs}$ potential. In the quadrature ac polarograms $\left(\mathrm{Y}{ }_{\mathrm{el}} \mathrm{Vs} \mathrm{E}\right)$ however, the experimental plot is slightly above the theoretical plot indicating reactant adsorption.

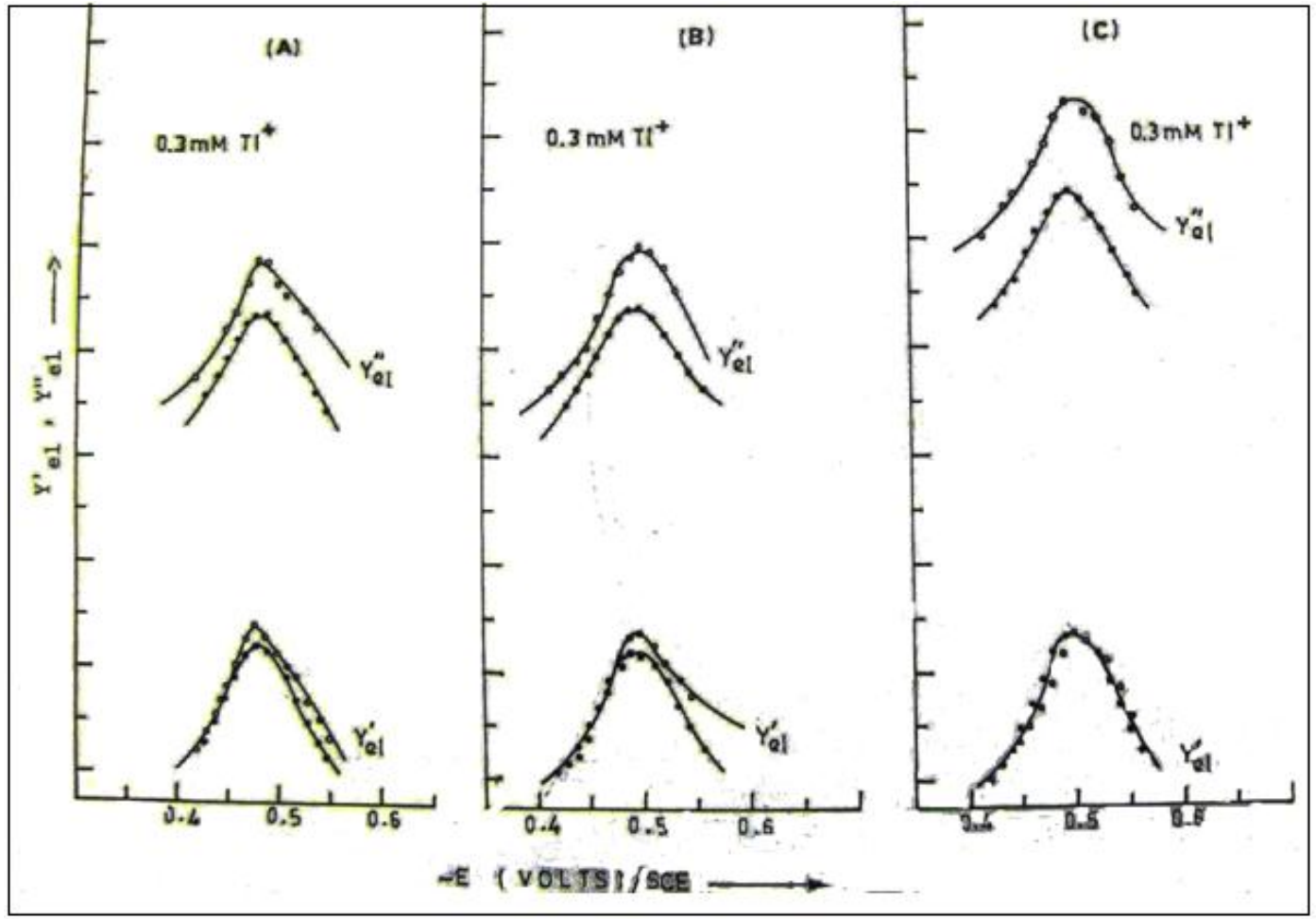

Figure 9. Theoretical plots (A) $0.5 \mathrm{M} \mathrm{NaClO}_{4}$ System; (B) $0.5 \mathrm{M} \mathrm{KNO} \mathrm{KN}_{3}$ System; (C) $0.5 \mathrm{M} \mathrm{KCl}$ System. 
In a similar manner, plots are made for Thallium (I) $-0.5 \mathrm{M} \mathrm{KNO}_{3}$ and Thallium (I)- $0.5 \mathrm{M} \mathrm{KCl}$ systems. For both systems, experimental in phase component is slightly lying above the theoretical one whereas experimental quadrature component is well above the theoretical one indicating adsorption effects.

\subsection{Calculation of $K_{\mathrm{s}, \mathrm{h}}$ values}

The rate constants were calculated using the equation, applicable for reversible reduction (Sridhar and Subrahmanya, 2010; Subramanianand Kalyanasundaram, 2012; Timmer et al., 1968b).

$\Theta_{\mathrm{rev}}=\left[\mathrm{RT}\left(\mathrm{D}_{\mathrm{R}} / \mathrm{D}_{\mathrm{O}}\right)^{(1-\alpha) / 2}\right] /\left[\mathrm{n}^{2} \mathrm{~F}^{2} \mathrm{~K}_{\mathrm{s}, \mathrm{h}}\left(\mathrm{C}_{\mathrm{O}}+\left(\mathrm{D}_{\mathrm{R}} / \mathrm{D}_{\mathrm{O}}\right)^{1 / 2} \mathrm{C}_{\mathrm{R}}\right) \alpha^{\alpha}(1-\alpha)^{(1-\alpha)}\right]$

The values are provided in the table 5 .

\section{CONCLUSION}

For all the three systems, $\mathrm{K}_{\mathrm{s}, \mathrm{h}}$ values have been calculated assuming the basic Randles and Laitinen (1955) equivalent circuit holds good. Earlier workers used either $\mathrm{C}_{\mathrm{d}}$ of the supporting electrolyte or some value calculated on the basis of different equivalent circuits. In the presence of reactant adsorption, $\mathrm{C}_{\mathrm{d}}$ of the blank should not be used. In Thallium (I)-0.5 $\mathrm{M} \mathrm{NaClO}_{4}$ system, $\mathrm{C}_{\mathrm{d}}$ of the system does not depend on the concentration of the depolarizer. This shows the absence of reactant adsorption. But at the same time, $\mathrm{C}_{\mathrm{d}}$ obtained from extrapolation method does not agree with the $\mathrm{C}_{\mathrm{d}}$ of the blank and differ by $2.1 \mu \mathrm{F} / \mathrm{cm}^{2}$. Further computation of $\mathrm{Z}_{\mathrm{f}}$ and $\mathrm{Z}$ ', ${ }_{\mathrm{f}} \mathrm{using}$ $C_{d}$ of the blank indicate that $Z^{\prime}$, values are lower than $Z{ }^{\prime}{ }_{f}$. The trend is reversed only when the value of $\mathrm{C}_{\mathrm{d}}$ as obtained from the extrapolation method is used. This nominal adsorption is confirmed in theoretical phase sensitive ac polarograms. For Thallium (I)- $0.5 \mathrm{M} \mathrm{NaClO}_{4}$ system, the experimental and theoretical in phase components agree with each other, whereas experimental quadrature component is above the theoretical one indicating adsorption effects. Further, theoretically calculated $\mathrm{Y}^{\prime}$ el $\mathrm{Y}^{\prime}$, ${ }_{\text {el }}$ values plotted along with experimental values lie parallel to experimental plots but making different intercepts. From the intercept, the $\mathrm{C}_{\mathrm{d}}$ has been found to be identical with that of blank. This fact further supports the concept of nominal adsorption, an adsorption which is independent of the concentration of the depolarizer but different from that of blank.

In the case of Thallium(I)- $0.5 \mathrm{M} \mathrm{KNO}_{3}$ and Thallium(I)- $0.5 \mathrm{M} \mathrm{KCl}$ systems, $\mathrm{C}_{\mathrm{d}}$ has been found to depend on depolarizer concentration indicating the reactant adsorption. Sluyters has pointed out 
that in presence of reactant adsorption, $\mathrm{Y}^{\prime}{ }_{\text {el }} \mathrm{Vs} \mathrm{Y}^{\prime}$ el plot will result in a distortion. But no distortion is observed in both the systems. The theoretical $\mathrm{Y}^{\prime}$, el $\mathrm{Vs} \mathrm{Y}^{\prime}$ el plots lie below the experimental plot but still intercept at the same point as required by the theory. Further the phase sensitive ac polarograms confirms a weak reactant adsorption in Thallium(I)-0.5M KNO 3 and a strong reactant adsorption in Thallium(I)-0.5M KCl system.

The three systems show different degree of adsorption effects and high degree of reversibility. The rate constant, $\mathrm{K}_{\mathrm{s}, \mathrm{h}}$ values are found to be greater than one. The investigation establishes the validity of simple Randles and Laitinen (1955) equivalent circuit even in presence of reactant adsorption.

\section{ACKNOWLEDGEMENTS}

The authors are grateful to the Head, Department of Chemistry and the Principal, Government Arts College, Coimbatore, India for their periodical encouragements and suggestions throughout the research work.

\section{REFERENCES}

Baticle, A.M \& Perdu, F.1967. Adsorption et impedance faradique: IIEtude experimentale. J.Electro.Anal.Chem.,13:364.

Grahame, D.C. 1949. Measurement of the capacity of the electrical double layer at a Mercury Electrode.J.Amer.chem.soc.,71: 2975-2978.

Llopis,J., Fernandez-Bearge, J \& Perez-Fernandez, M. 1959.Study of the impedance of a platinum electrode in a redox system.Electrochim.Acta,1:130-145.

Lorenz, W\& Salie, G. 1961. Mechanism of the Electrochemical Phase Boundary Reaction, Z. Physik.Chem., 218:259-271.

Randles, J.E.B. 1947. Kinetics of rapid Electrode Reactions. Discussions of theFaraday soc., 1: 11-19.

Randles, J.E.B \& Laitinen, H.A. 1955. Transfer and retardation in the polymerization of vinyl acetate. Trans.Faraday soc.,51: 543.

Senda, M \& Delahay, P. 1961. Rectification by the electrical double layer and adsorption kinetics. J.Phys.Chem., 65:1580-1588. 
Sluyters-Rehbach, M \& Sluyters, J.H. 1963a. On the impedance of galvanic cells: VI Alternating current polarography in the complex impedance plane: General treatment. Rec.Trav.Chim.Pays-Bas, 82:525-534.

Sluyters-Rehbach, M \& Sluyters, J.H. 1963b.On the impedance of galvanic cells:VII .Alternating current polarography in the complex impedance plane, experimental verification. Rec.Trav.Chim.,82: 535-552.

Sluyters-Rehbach,M., Kooijman, D.J\& Sluyters, J.H. 1964. Polarography(G.J.Hills, (ed.), Mac.Millan, London, 135p.

Sluyters-Rehbach M \& Sluyters J. H.1970. Electro analytical Chemistry (A. J. Bard, (ed.)), Marcel Dekker, New York.4: 1.

Smith, D.E.1966. Electroanalytical Chemistry (A.J. Bard (ed.)), Marcell Dekker,New York.

Somayaji,B.M \& Subramanya,R.S. 1969. Ph.D Thesis, Indian Institute of Science, India.

Sridhar,P \& Subrahmanya, R.S. 2010. D.C., A.C. and Complex Plane Polarographic Behaviour of Copper (II) in Monoethanolamine, Sodium Perchlorate/Monoethanolammonium Perchlorate Solutions.DOI: 10.1002/bscb.19840930101, Wiley online library.

Subramanian,P.A \& Kalyanasundaram,R..2012.Studies on the Kinetic Parameters of Thallium(I) - 50\%Methanol-Water Mixture at DME by Faradaic Impedance Technique.Der Pharma Chemica, 4 (3):819-833.

Tamamushi, R \& Tanaka, N. 1961. On the reduction process of Thallium(I) at the dropping mercury electrode.Z.Physik.Chem.N.F., 28:158-167.

Timmer, B., Sluyters-Rehbach, M \& Sluyters, J.H. 1968a. On the impedance of galvanic cells: XXIII Electrode Reactions with Specific Adsorption of the Electroactive Species: The $\mathrm{Pb} 2 / \mathrm{Pb}(\mathrm{Hg})$ Electrode in MKND3-kd Mixtures.J.Electroanal.Chem.,18:93.

Timmer, B., Sluyters-Rehbach, M \& Sluyters, J.H. 1968b.On the impedance of galvanic cells: XVIII The potential dependence of the faradaic impedance in the case of an irreversible electrode reaction and its application to A.C. polarography. .J. Electroanal. Chem., 14: 169-180. 